\title{
Susceptibility of some Cucumber Plant Varieties to the Infestation by Certain Piercing Sucking Insects
}

\author{
Darwish, A. A. ; A. Abd-Elsamed and Eman M. F. Arafa \\ Benha University, EGYPT \\ Plant protection Department, Feculty of Agric. Benha University, EGYPT \\ Plant Prot. Res. Inst., Agric. Res. Cent., Dokii, Giza, Egypt
}

\begin{abstract}
These experiments were carried out at Menya AL- Qamh district, Sharkia governorate, during two growing seasons of 2016 and 2017 cucumber, Cucumis sativus plants. Varieties Sahim - El-prince and Beit alpha were planted to study their infestation with some pests aphid, leafhopper, mite, whitefly and thrips and the relationship between some chemical contents (Lipids, carbohydrate, protein and $\mathrm{pH}$ values) of the varieties and their infestation by Aphis gossypii (Glov.), Empoasca decipiens (Paoli) Empoascya decedens (Paoli). Bemesia tabaci (Genn.), Tetranychus cucurbitacearum (Sayeg), and Thrips tabaci (Lind). The obtained results showed that the susceptibilty of cucumber varieties to pest infestation could be arranged descendingly according to the number of pests as follows: Beit alpha, El -prince and Sahim. Chemical analysis results indicated the increase in protein and carbohydrate contents caused on increased the mean number of some pests infested these varieties cucumber, while studied those increase of $\mathrm{pH}$ values led to decrease the mean number of pests and their rate of infestation.
\end{abstract}

Key words: Cucumber, varieties, pest infestation, chemical analysis .

\section{Introduction}

Aphids, leafhoppers, thrips, whitefly and mite are considered serious pests infesting cucumber plants. The plants are infested by the aforementioned pests which affect the yield as results of their direct feeding on plants. Several investigators recorded the role of homopterous insect species in transmitting the pathogens of plants diseases (El Gindy, 2002 ) and Al-Habshy, Aml (2018). who studied the life table data of Aphis gossypii on two cucumber varieties(c.v.). developmental time of A. gossypii on Aramon cultivar was approximately $20 \%$ longer at all temperatures. Mortality of immature stage did not differ between two varieties. The intrinsic rate of increase on CV. Aramon was 15\% smaller than CV. Sporu (Steenis and El - Khawass, 1995). Dawood 1999 estimated the average number of $B$. tabaci adults and immature stages on three cucumber varieties under field conditions of Beni-Sweif governorate, Egypt. For cucumber varieties, Sliberti hybrid was the least susceptible. Hafiz, 2002 indicated that $\boldsymbol{A}$. gossypii had faster nymphal development on Tamra 761 variety, Rawa Fl-Rs and Fl- hybrid Beit alpha MR compared with Beit alpha MR, Beth alpha MR Fl-hybrid, Beth alpha MR and Hezara 480 varieties. The infestation of seven cucumber varieties by $T$ thapci (nymph and adults) was as follows, the highest infestation rate was occurred on Ivor variety followed by Prince variety. When the lowest infestation occurred on Babylon and Al- Zaeim variety .Highest seasonal mean count of aphids was detected on leaves of El-Nems variety. While the lowest rates of infestation by aphids occurred on Thamin and Ivor. Super-Delila, Thamin and Prince verities recorded higher infestation levels by
B. tabaci different stages. The highest infestation rate of $T$. urticae was occurred on Thamin and Prince Hanafy, 2004. Also, the same author reported that aphids increased by delaying the planting date on cucumber plants. Abd-Elsamed et al., (2018) investigated the susceptibility of different solanaceous plant varieties, egg plant, pepper, tomato to the infestation by certain piercing sucking pests.

The present study aimed to investigate susceptibility cucumber plants infestation with aphid, leafhopper, thrips, whitefly and mites during years 2016 and 2017 and the relationship between these pests aphid, leafhopper, thrips, whitefly and mites and chemical analyses

\section{Materials and Methods}

An area about $2100 \mathrm{~m} 2$ was chosen to carry out this investigation at Menya Al-qamh district, Sharkia governorate, the experimental design was completed randomized plot with three replicates. Treatment was distributed as replicate each plot consisted four rows (4 meters long and 14 meters wide). Each replicate was divided into 18 lines; the space between hols were $25-30 \mathrm{~cm}$. Planting date of the tested cucumber plants were during the first week of April , in 2016 and 2017 seasons, sampling were started when the age of the plants reached about 21-28 days and continued weekly intervals until 1st week of May. The normal agricultural practices were followed in due time and all plots were kept free of any insecticide treatment. The varieties of the three cucumber plants were (Beit alpha, El-prince and Sahim), 


\section{Plant samples}

15 leaves per replicate representing different upper, middle and bottom parts were picked out randomly from each variety. These leaves were examined in the laboratory at the same day using a binocular microscope and the total number of existing of aphid, whitefly, Thrips and mite pests on both surfaces of the leaves were recorded.

\section{Sweep net}

$30 \mathrm{~cm}$ diameter and $60 \mathrm{~cm}$ deep. Each sample consisted of 100 double strokes were taken from both diagonal directions of the experimental area. Each sample was kept in a tight closed paper bag and transferred to the laboratory for inspection by binocular microscope at the same day and the collected leafhoppers were killed by using killing jar cyanide, sorted into species and identified according to the work of Hegab et al. (1989). Counts of captured leafhoppers were recorded for each sample.

Determination of total protein, carbohydrates contents and PH values. Samples were taken at random from each variety when there were peaks of pests and oven dried at $60^{\circ} \mathrm{C}$ tell constant weight. The dried leaves cucumber varieties were finally ground and digested with a mixture of perchloric acid and nitric acid (2:1).

\section{Determination of some chemical contents:}

To determine total protein, carbohydrate contents and $\mathrm{pH}$ values, leaf samples were taken at random from each variety when there were peaks of pests and oven dried at $60^{\circ} \mathrm{C}$ until the constant weight. The dried leaves cucumber were finally ground and digested with a mixture of perchloric acid and nitric acid (2:1). Chemical analysis of the used cucumber varieties were carried out in central laboratory, Faculty of Agriculture, Benha University to determine the total lipids, carbohydrate contents, protein, and $\mathrm{pH}$ value

\section{Determination of protein content}

Total nitrogen in cucumber plants was estimated according to Bremner and Mulvaney (1982). The crude protein content was obtained by multiplying the nitrogen content by the factor 6.25 .

\section{Determination of carbohydrate content}

The total carbohydrates content in cucumber plants were determined calorimetrically using the anthrone reagent and the color intensity was measured at $240 \mathrm{~m} \mu$ following the method described by Dubois et al., (1956).

\section{Determination of $\mathrm{pH}$ value}

$\mathrm{PH}$ value was estimated in the plant sap using $\mathrm{pH}$ meters.

\section{Statistical Analysis}

The chemical constituents of cucumber varieties at the infestation density of the aforementioned homopterous insects were statistically analyzed Costat (2005) The means were compared according to Duncan's multiple range test Snedecor and Cochran (1981).

\section{Results and Discussion}

1- Susceptibility of different cucumber varieties on population density by certain piercing sucking pests infesting cucumber:

A ) Aphis gossypii

As shown in Table (1) the differences between mean numbers of aphid on cucumber varieties during the two seasons were obviously high significant. The most susceptible variety was Beit alpha (2379.00 and 3113.33 insect/ plant sample) in the two seasons 2016-2017, respectively, while the least susceptible variety was Sahim that recorded total numbers of 323 and 834 insects/plant sample in 2016 and 2017 seasons, respectively.

\section{B ) Empoasca decipiens}

As shown in Table (1) the differences between the mean numbers of $E$. decipiens on cucumber varieties during the two seasons proved to be statistical significant. The most susceptible variety was Beita alpha (350 and 380) insects/ sweep net in both seasons, respectively, while the least susceptible variety was Sahim which 301.33 and 260 recorded insects/sweep net in the net in both seasons, respectively.

\section{C ) Empoasca decedens}

As shown in Table (1) the incidence of total number of the leafhopper $E$. decedens on cucumber varieties were greatly varied during the two seasons . The most susceptible variety was Beita alpha indicated (239 and 290) insects / sweep net) for $E$. decedens in both seasons, respectively. While the least susceptible variety was Sahim which 197and 164 recorded insects / sweep net in both seasons , respectively .

\section{D ) Bemisia tabaci}

Data given in Table (1) showed that the differences between mean numbers of whitefly $B$. tabaci (immatures and adults) infested cucumber plant varieties during the two seasons. Sahim variety was the least susceptible host plant for immatures infestation showing 625 and 995 immatures / plant sample, while the variety Beit alpha appeared to be the most susceptible cucumber variety (2368 and 1227 immatures /sample) during the two seasons, respectively. The most susceptible variety was Beitalpha 1359.33 and 814 adults /plant in both seasons, 
respectively, while the least susceptible variety was Sahim recorded (508 and 786 adults / sample) for adults in both seasons, respectively.

\section{E ) Tetranychus cucurbitacearum}

As shown in Table (1) the differences between mean numbers of mite infested cucumber plant varieties during the two seasons were obviously differed. The most susceptible variety was Beit alpha which 3283 and 3220 egg / sample recorded in the two seasons, respectively, while the least susceptible variety was Sahim that recorded mean numbers of 921 and 1233 egg /sample for eggs in 2016 and 2017 seasons, respectively, while the most susceptible variety was Beit alpha which 2266 and 2207 adult / sample recorded in the two seasons, respectively, while the least susceptible variety was Sahim that recorded mean numbers of 701 and 636 adult/ sample for adult in 2016 and 2017 seasons, respectively

\section{F ) Thrips tabaci}

Data given in Table (1) showed the differences between mean numbers of $T$. tabaci infested cucumber plant varieties during the two seasons. Sahim variety was the least susceptible host plant for T. tabaci infestation showing 1320 and 1258 insects / sample. While the variety Beit alpha appeared to be the most susceptible cucumber variety (2082 and 2815 ) insects during the two seasons, respectively.

Generally, from the obtained results, Beit alpha variety was more susceptible to aphid, whitefly and leafhopper pests infestation, whereas Sahim variety was the least susceptible cultivar.

\section{2- The influence of cucumber verities on the yield}

With respect to the influence of cucumber varieties on the yield, data presented in Table (1) showed that Sahim variety was the highest yield with 78.75 and $88.6 \mathrm{~kg} / \mathrm{plot}$ in the two seasons, respectively. While, Beit alpha variety was the lowest yield with 44.87 and $51.56 \mathrm{~kg} / \mathrm{plot}$ in the two seasons, respectively.

Hafiz (2002) indicated that A. gossypii had faster nymphal development on Tamra 761 variety, Rawa Fl-Rs and Fl- hybrid Beit alpha MR compared with Beit alpha MR, Beth alph MR Fl-hyrid, Beth alpha MR and Hezara 480 varieties. Hanafy (2004) mentioned that, the infestation of the pests of seven cucumber varieties the highest infestation rate of T. tabaci was occurred on Ivor varieties. While the lowest rates of infestation by aphids occurred on Thamin and Ivor. The highest infestation rate of $T$. urticae was occurred on Thamin and Prince. Also, reported aphids increased by delaying the planting date on cucumber plants.

3) Relation between some chemical contents of cucumber varieties and population density of certain piercing sucking pests

Data given in Table (2) showed the effects of different chemical contents of cucumber varieties on the infestation by aphid, leafhopper, mite, whitefly and thrips during 2017 season.

Beita alpha variety recorded the mean numbers of A. gossypii, E. decipiens, E. decedens, B. tabaci (immatures), B. tabaci (adults), T. cucurbitacearum (egg), T. cucurbitacearum (adult) and T. tabaci of 3113.33, 380,290, 1227, 814, 3202, 2207 and 2815 pests/sample in years of 2017, respectively. Also, 5.02 total lipids, $17.7 \%$ carbohydrate contents, $20.07 \mu / \mathrm{m}$ total protein and $3.65 \mathrm{pH}$ on the other hand. Sahim variety recorded the mean numbers of $A$. gossypii, $E$. decipiens, E. decedens, B. tabaci (immatures), B. tabaci (adults), T. cucurbitacearum (egg), $T$. cucurbitacearum (adult) and T. tabaci of 834, 260, 164, 995, 786, 1233, 636 and 1258 pests/sample, respectively with 4.19 total lipids, $15.68 \%$ carbohydrate contents, $17.11 \mu / \mathrm{m}$ total protein and $5.81 \mathrm{pH}$, during 2017 season.

Generally, from the obtained results indicated that the increasing of cucumber total protein and carbohydrate contents led to the increase of the mean number of pests infestation. But the increase in $\mathrm{pH}$ value, led to decrease the mean number of insects and mites on cucumber. Sahim verities was the least susceptible to pests infestation and gave the highest yield El - Gindy (2002); Hashem (2005) Youssef (2006); Al-Habshy et al., (2011); Hegab et al., (2014); Amer (2016) and Abd-Elsamed, et al.,(2018) pointed out that the chemical constituents of some graminaceous, leguminous, solanaceous, cucurbitaceous and broad bean plants varieties were effective on the population density of aphid, leafhopper, thrips, whitefly and mites. 
Table 1. Susceptibility of cucumber varieties to aphid, leafhopper, whitefly, thrpis , and mite pests infestation during 2016 and 2017 seasons at Menya Elkamh, Sharkia governorate

\begin{tabular}{|c|c|c|c|c|c|c|c|c|c|c|c|c|c|c|c|c|c|}
\hline \multirow{3}{*}{ 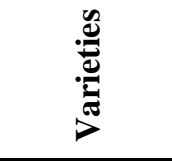 } & \multirow{2}{*}{\multicolumn{2}{|c|}{$\begin{array}{c}\text { Aphid } \\
\text { A. gossypii } \\
\end{array}$}} & \multicolumn{4}{|c|}{ leafhopper } & \multicolumn{4}{|c|}{ B. tabaci } & \multicolumn{4}{|c|}{ T. cucurbitacearum } & \multirow{2}{*}{ Thrips } & \multirow{2}{*}{ tabaci } & \multirow{2}{*}{ Yield kg/plot } \\
\hline & & & \multicolumn{2}{|c|}{ E. decipiens } & \multicolumn{2}{|c|}{ E. decedens } & \multicolumn{2}{|c|}{ Immature stages } & \multicolumn{2}{|c|}{ Adult stages } & \multicolumn{2}{|c|}{ egg } & \multicolumn{2}{|c|}{ adult } & & & \\
\hline & 2016 & 2017 & 2016 & 2017 & 2016 & 2017 & 2016 & 2017 & 2016 & 2017 & 2016 & 2017 & 2016 & 2017 & 2016 & 2017 & $2016 \quad 2017$ \\
\hline Beit alpha & $2379^{a}$ & $3113.33^{\mathrm{a}}$ & $350^{\mathrm{a}}$ & $380^{\mathrm{a}}$ & $239.0^{\mathrm{a}}$ & $290.0^{\mathrm{a}}$ & $2368.0^{a}$ & $1227.0^{\mathrm{a}}$ & $1359.33^{\mathrm{a}}$ & $814.0^{\mathrm{a}}$ & $3283^{\mathrm{a}}$ & $3220^{a}$ & $2266.0^{\mathrm{a}}$ & $2207^{a}$ & $2082^{a}$ & $2815^{\mathrm{a}}$ & $44.87 \quad 51.56$ \\
\hline El-Prince & $1549^{\mathrm{b}}$ & $926^{\mathrm{b}}$ & $330.6^{\mathrm{b}}$ & $270.13^{b}$ & $208.7^{\mathrm{b}}$ & $189.2^{\mathrm{b}}$ & $1923^{b}$ & $999.0^{\mathrm{b}}$ & $940^{\mathrm{b}}$ & $773.0^{\mathrm{a}}$ & $2845^{\mathrm{b}}$ & $2280^{\mathrm{b}}$ & $1128.33^{\mathrm{b}}$ & $1887.67^{\mathrm{b}}$ & $1970^{\mathrm{a}}$ & $2430^{\mathrm{b}}$ & 64.1970 .96 \\
\hline Sahim & $323^{c}$ & $834^{\mathrm{b}}$ & $301.33^{\mathrm{ab}}$ & $260.0^{\mathrm{b}}$ & $197.0^{\mathrm{ab}}$ & $164.0^{c}$ & $625^{\mathrm{c}}$ & $995.0^{\mathrm{b}}$ & $508 .^{\mathrm{c}}$ & $786.0^{\mathrm{a}}$ & $921.0^{\mathrm{c}}$ & $1233^{\mathrm{c}}$ & $701.0^{\mathrm{b}}$ & $636^{\mathrm{c}}$ & $1320.33^{b}$ & $1258^{c}$ & $78.75 \quad 88.60$ \\
\hline $\mathbf{F}$ & $* *$ & $* *$ & $*$ & $* *$ & $*$ & $*$ & $* *$ & $*$ & $* *$ & ns & $* *$ & $* *$ & $*$ & $* *$ & $* *$ & $* *$ & $* *$ \\
\hline L.S.D 0.05 & 122.95 & 669.71 & 68.05 & 116.686 & 54.221 & 61.22 & 190.31 & 175.35 & 295.89 & 142.122 & 252.74 & 245.19 & 971.5 & 272.24 & 152.43 & 283.17 & $11.819 \quad 6.46$ \\
\hline
\end{tabular}

Table 2. Effect of some chemical contents of three cucumber verities on the percent of infestation of certain hemipterous and mite pests

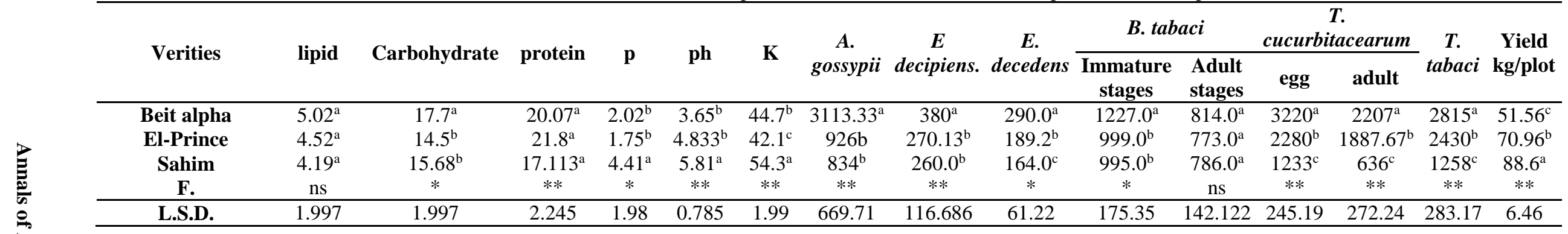




\section{References}

Abd Alla, Z. M. (1984): Studies on aphids in Sharkia region. Ph.D. Thesis, Fac. Agric., Zagazig Univ. Egypt.

Abd-Elsamed A. A. A. , M.S. Hashem and Aml Z.N. Al-Habshy (2018):

Susceptibility of different solanaceous plant varieties to the infestation by certain piercing sucking pests at El-Kasasine district, Ismailia governorate, Egypt. Zagazig Journal of Plant Protection and Pathology Research. 45:(1) .

Al-Habshy, Aml Z.N., A.A. Abd-Elsamed and M.A. Ahmed (2011). Effects of certain agricultural practices on the infestation of soybean plants by some homopterous insect pests at DiarbNigm district Sharkia Governorate. J. Plant Prot. and Pathol. Mansoura Unvi. , 2 (7): 721- 729.

Al-Habshy, Aml Z.N. (2018): Cowpea aphid Aphis craccivora Koch as insect vector of Faba bean necrotic yellow virus (FBNYV) on broad bean plants. J. Plant Prot. and Path., Mansoura Univ., Vol. 9 (1): $31-33$.

Amer, S.A.M. (2016): Studies on some piercingsucking insects infesting certain field crops and their predators in Sharkia Governorate. Ph.D. Thesis, Fac. Agric., Benha Univ., Egypt.

Bremner, J.M. and C.S. Mulvaney (1982): Total Nitrogen. In (Page, A.L., R.H. Miller and D.R. Keeney (Eds)): Methods of Soil a analysis, Part 2, Amer. Soc, Agron. Madison.

CoStat Statistical Software, (2005): . Microcomputer program analysis Version, 4.20, CoHort Software, Berkeley, CA.

Dawood, M. Z. (1999): Susceptibility of certain commonly cultivated squash and cucumber cultivars to Bemisia tabaci (Genn.) (Homoptera :Alyrodidae )in Beni - Suef governorate . Egypt J. Agric .Res. , 77(3) : 1075-1079

Dubois, M., K. Giles, J.K. Hamilton, P.A. Rebvs and F. Smith (1956): Colorimetric method for determination of sugars and related compounds. Anal. Chem., 28: 350-356.

El-Gindy, M.A. (2002): Studies on certain homopterous insect vectors of plant pathogenic diseases. Ph.D. Thesis, Fac. Agric., Zagazig Univ.,Egypt : 263pp.

Hafiz, N. A. (2002): Effect of certain cucumber varieties on the biological of Aphis gossypii (Homoptera: Aphididae) $.2^{\text {nd }}$ international conference. Plant protection research Institute. Cairo, Egypt . 1:847-849.

Hanafy, A. R. I. (2004): Studies on the most important cucumber pests in the open field and suitable control programs . Ph . D. Thesis ,Fac. of .Agric. Moshtohor, Benha Branch -Zagazig Univ, Egypt .

Hashem, M.S. (2005): Studies on certain piercingsucking insects infesting some vegetable crops. Ph.D. Thesis, Fac. Agric., Moshtohr, Zagazig Univ., Egypt: 323pp.

Hegab, A.M.; I.M. Kelany and M.M. EI-Maghraby (1987): Survey of leafhoppers and planthoppers infesting maize plants by using three sampling techniques in newly reclaimed sandy areas at Salhia district, Egypt. Minia J. Agric. Res., 9 (2): 945-953.

Hegab, M.A.; A.E. Ibrahium A.A; Shahein and Jasmien E. Abdel-Magid (2014): Susceptibility of certain solanaceous plant varieties to some homopterous insects infestation. J. Entomol., 11 (4): $198-209$.

Snedecor, G.W. and W.G. Cochran (1981): Statistical methods 7th Ed. 570 Iowa Stat., Univ. Press., Ames Iowa, USA.

Steenis Van. M. J. and K. A. M. H. El- Khawass (1995): Life history of Aphisgossypii on cucumber influence of temperature, host plant and parasitism . entomo . Experimentaliet Applicated 76, (2): 121-131.

Youssef, A.A.A. (2006): Studies on some homopterous insect vectors of plant diseases. Ph.D Thesis, Fac. Agric.Zagazig Univ. 


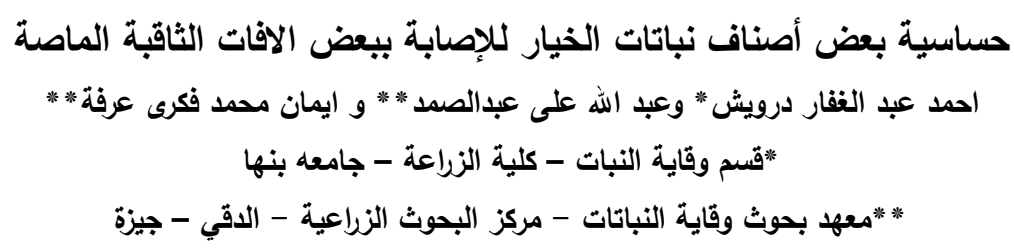

أجريت هذه الدراسـة في منطقة منيا القمح محافظة الثـرقية على نباتات الخيار خلال 2016 و و2017 ـ على الأصناف (سهم والبرنس وبيتا

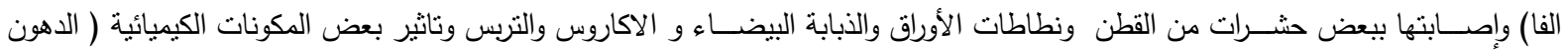

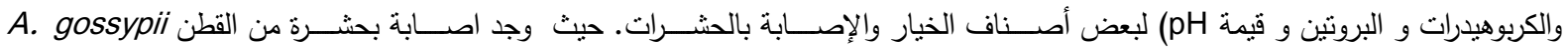

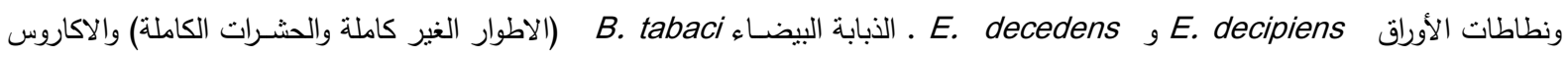

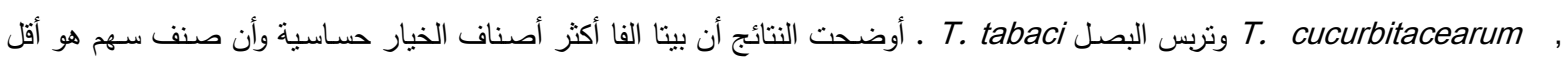

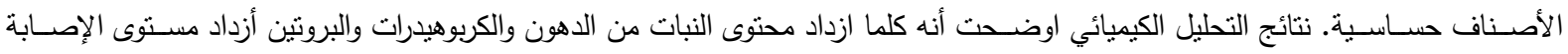

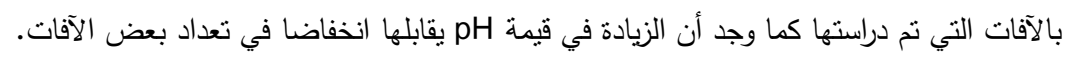

